\title{
Security and stability in Southwest Asia
}

\author{
William Maley
}

On 11 September 2001, al-Qa'ida's attacks on the World Trade Center and the Pentagon triggered a sequence of events which transformed the security environment of Southwest Asia. Not since the assassination of Archduke Franz Ferdinand in Sarajevo on 28 June 1914 had the action of non-state actors impacted so dramatically upon world affairs. The introduction of US power into the region, the US decision to adopt Pakistan as an ally once it committed itself to abandon support for the Taliban who in neighbouring Afghanistan had provided refuge for al-Qa'ida's leader Osama bin Laden, and the subsequent overthrow of the Taliban forced a range of actors to re-position themselves to cope with new realities. Yet questions remain as to how enduring the US presence will prove, and how effective it will be in addressing the region's deep-seated problems.

Southwest Asia is one of the most troubled parts of the world, and only an optimist would adopt a sanguine view of its prospects in the short-to-medium term. An analyst searching for examples of interstate rivalry, institutional decay, ethnic tension, weapons proliferation and territorial disputes would not have far to look. Afghanistan and Pakistan spring immediately to mind as tragic venues for these problems, which all have the potential to lead to violence and disruption to the lives of ordinary people. At the same time, the region is home to the world's largest democracy, India, a state which for over half a century has defied gloomy expectations of fragmentation and instead emerged as an increasingly dynamic economic actor, with real potential to ascend to the status of a Great Power. The benefits which could accrue to Southwest Asia from interstate cooperation instead of antagonism are considerable.

Regional boundaries are always imprecise and fluid, for they reflect the interaction of diverse influences, expectations and perceptions on the part of actors which are themselves subject to change. In this chapter, I use the term 'Southwest Asia' principally to embrace the states of Afghanistan, Pakistan and India. The 
justification for this focus is the significance of developments in these states for the stability of the wider world. Rivalry between India and Pakistan is a poisonous legacy of the partition of the subcontinent in 1947, and since the Indian and Pakistani nuclear tests in 1998 it has rarely been far from the concerns of most mature world leaders. Afghanistan, plunged into disarray by the communist coup of April 1978 and the Soviet invasion of December 1979, not only became a breeding ground for profoundly unappetizing forms of extremism, but has been a theatre in which rivalries between other regional actors have been conducted. These considerations justify detailed discussion of the politics of these states. It is important, however, to recognize that these states have not functioned in a static political context. The collapse of the USSR in 1991 involved not simply the final breakdown of a sociopolitical order based on Marxism-Leninism, but also the disintegration of a vast territorial state. The emergence of new states from the wreckage of the Soviet Union prompted hopes that the energy resources of Central Asia could be further exploited, and this reconfiguration of regional structures was to have serious consequences (Canfield 1992) - especially for Afghanistan, where the belief that the radical Taliban movement could provide security for oil and gas pipelines led to its being regarded with a fatally friendly gaze by Islamabad and Washington (Maley 1998).

The aim of this chapter is to explore the roots of some of the key problems of Southwest Asia. My approach is an eclectic one, designed to capture some of the complexities which make progress in improving the regional political climate so difficult to obtain. The chapter is divided into six sections. The first examines the key interstate tensions and border disputes which bedevil the region, notable the India-Pakistan, Pakistan-Afghanistan, and China-India problems. The second is concerned with the ways in which state failure has affected Southwest Asia: here, the two states on which I focus are Afghanistan, a paradigmatic case of state failure, and Pakistan, which is a threshold failed state. The third considers the special place of India in the region, and the trajectory of its internal political and social development. The fourth explores the implications of weapons proliferation for stability, and the fifth assesses the implications of 'non-traditional' security threats. The last offers some brief conclusions.

\section{Interstate tensions and border disputes}

The boundaries between the key states of Southwest Asia represent the detritus of past colonial experience, and for that reason alone a number of them remain highly contested. But as well as the burdens of history, these boundaries carry the weight of ongoing antagonisms, which aggravate and intensify the symbolism of 'artificial' demarcation of the territorial state.

The relationship in which this is most pronounced is that between India and Pakistan. The hostility between India and Pakistan is longstanding, deep-rooted, and the most serious source of peril for the region. It is grounded in the legacy of the partition of British India into Hindu-majority and Muslim-majority states, 
which affected relations between the two successor states in complex ways. On the one hand, partition triggered the displacement of vast numbers of people, creating legacies of bitterness and sorrow which cannot easily be set aside (Pandey 2001). On the other hand, the partition process gave rise to fresh challenges of territorial integrity, both immediate and latent. Partition is rarely neat and never simple. The most intractable legacy of partition is the Kashmir dispute.

The Kashmir story is complex and contested (Ganguly 1997), but at heart it involved the attachment of a Muslim-majority territory to a Hindu-majority state at the instigation of its Hindu ruler. This development set up a tension between two different legitimacies: one procedural, based on the mechanism of accession, and the other substantive, based on religious identity. Not surprisingly, India emphasized the salience of procedure, while Pakistan emphasized the importance of identity. The two states went to war over Kashmir in 1948 and 1965, and to the brink of war in 1999 after the Kargil incursions. There is no mutually-accepted border between the two states in this part of the world: rather, a 'Line of Control' exists between the two, with India in control of the southern and eastern parts of Kashmir (except for a portion occupied by China in the northeast), and Pakistan in direct control of parts of historic Kashmir to the north of the Line of Control, and in effective control of 'Azad Kashmir' to the west. The Siachen Glacier, to the north of the Line of Control, is a particular flash point (Khosa 1999). In early 1999, the then leaders of India and Pakistan, Atal Behari Vajpayee and Muhammad Nawaz Sharif, had made an effort to explore possible solutions to the Kashmir dispute in a 'second-track dialogue in which Pakistan was represented by former Foreign Secretary Niaz Naik, and India by the newspaperman R.K. Mishra (Bennett Jones 2002, 95-6). However, such progress as the representatives made was then torpedoed by the adventurism of the Pakistan military over Kargil. The fundamental problem of Kashmir is that a territorial dispute that could be solved with creative thinking is now so entangled in the domestic politics of both India and Pakistan that shifting the parties from their long-held and irreconcilable positions has become extraordinarily difficult. Standing firm over Kashmir has become a symbolic measure of a leader's loyalty to the identity of India or Pakistan, and it would take considerable political (and perhaps even physical) courage for a leader to contemplate a shift.

If Pakistan is in dispute with India over Kashmir, it has also spent much of its life in border dispute with its western neighbour Afghanistan. Indeed, Pakistan's relentless attempts in recent years to hold sway in Afghanistan can hardly be understood without reference to the historically poor relations between the two. Afghanistan actually opposed the admission of Pakistan to membership of the United Nations, and for most of the 1950s, 1960s and 1970s, Afghanistan, with an overwhelmingly Muslim population, was much closer to Hindu-dominated India than to Muslim Pakistan. The reason was the 'Pushtunistan' dispute. When Sir Mortimer Durand drew a boundary, the 'Durand Line', to separate Afghanistan from British India in 1893, he divided members of the Pushtun ethnic group 
between the two territories. Reuniting the divided Pushtuns was an objective of profound significance for the Pushtun-dominated Afghan elite, especially during the premiership of Muhammad Daoud from 1953 to 1963 (see Dupree 1973, 538-58; Ganguly 1998, 162 -92). Islamabad, as a generous host to Afghan refugees through the $1980 \mathrm{~s}$, had an historic opportunity to reverse the traditional pattern of its relations with Kabul, but it was an opportunity that Pakistan's leadership fumbled spectacularly by seeking to promote Islamic extremists to rule Afghanistan, first the Hezb-e Islami headed by Gulbuddin Hekmatyar, and then the Taliban. The Pushtunistan dispute is not at the forefront of relations between Pakistan and Afghanistan at present, but nor has it been resolved, and it could resurface with a vengeance at some point in the future.

The unresolved border problems between China and India should also be mentioned at this point. The courteous relations which currently prevail between Beijing and New Delhi have not typified the relationship in all its phases; on the contrary, in 1962, China used force with deadly effect against India to assert its control of disputed border territories (Nayar and Paul 2003, 79-83). In order to put this in context, it is necessary to recall the atmosphere of the early $1960 \mathrm{~s}$. While Indian Prime Minister Jawaharlal Nehru had gone out of his way to build a positive relationship with China, neither the United States nor the USSR had followed suit in the least: the United States was not to recognize the Beijing authorities as China's rulers until 1980, and from 1960 to 1989 , the Sino-Soviet dispute put paid to the notion of undivided world communism. In the aftermath of the border war, India was confronted not only with the challenge of interpreting the alarming signals which emanated from China during the Cultural Revolution, but also with managing the implications for the Non-Aligned Movement of inspirational Chinese rhetoric, particularly that associated with Lin Biao's Long Live the Victory of People's War. The post-Maoist deradicalization of China was a considerable relief to the Indian leadership, and left it disinclined to pursue issues left over from the early $1960 \mathrm{~s}$. Nonetheless, India contimues to station significant conventional forces adjacent to China, and apprehension about the future orientation of China has figured in Indian doctrine on force posture.

\section{State failure: Afghanistan and Pakistan}

Interstate tensions are perilous even when the states involved are internally wellordered, but they are particularly dangerous when a state is experiencing disnuption. On the one hand, command and control of armed force may be unreliable where the instrumentalities of the state are decaying. On the other hand, evidence of decay may tempt a neighbouring state either to meddle or to intervene directly as a way of furthering its own interests. Afghanistan and Pakistan provide clear illustrations of such phenomena.

Afghanistan's descent into disorder sprang from an accumulation of serious problems towards the end of the 1960s and into the 1970s. The fiscal basis for state-driven modernization of Afghanistan was shaky, and far too much state 
expenditure was funded from 'rentier sources', that is, foreign aid and asset sales (Rubin 2002, 296-7). In addition, the overthrow of the monarchy in July 1973 in a 'palace coup' staged by former prime minister Daoud, a cousin of the king, somewhat undermined the traditional legitimacy of the ruling dynasty, and in combination with the emergence of acute divisions within the Kabul-based national elite, set the scene for the communist coup of April 1978 (Maley 2002a, 15-17). The well-documented failings of the communist regime-its internal divisions, insensitivity, and vicious brutality-paved the way for the Soviet invasion of Afghanistan in December 1979. A reality too often overlooked is that the Afghan state as a mechanism for the extraction and mobilization of resources effectively collapsed around this time. Through the 1980s and into the early 1990 s, successive communist rulers were sustained by either Soviet troops or Soviet resources. The severing of resource flows when the Soviet Union itself collapsed led directly to the collapse of communist rule less than four months later. But the Afghan resistance forces that took over the symbols of state power, notably the capital Kabul, did not inherit workable state institutions, and even the Afghan army fragmented, largely along ethnic lines (Davis 1993). Furthermore, they found themselves under almost immediate attack from forces backed by Pakistan, which was eager to secure a return for its investment in the Afghan resistance. The southern suburbs of Kabul were blasted by Hezb-e Islami rockets and artillery from 1992 until 1995; thereafter, the rockets were fired by the Taliban, to whom Pakistan had shifted its backing (Rashid 2000; Dorronsoro 2002,170 ) in the face of the Hezb's inability to hold and occupy territory (as opposed to simply acting as a spoiler). The Taliban seizure of Kabul in September 1996 inaugurated a desperate period for ordinary Afghans, in which their country increasingly became an operating base for Arab extremist groups such as al-Qa'ida, and for forces backed by Pakistan, which found it convenient to base Kashmiri militants on Afghan territory. The ouster of the Taliban by the United States, its international allies, and anti-Taliban Afghan forces has not only reconfigured the region strategically, but set the scene for a massive task of social and institutional reconstruction in Afghanistan, which is of fundamental importance for regional stability, but far from simple or easy (Maley 2002b; Atmar and Goodhand 2002: Wimmer and Schetter 2002).

If Afghanistan is a deeply troubled state, so too is Pakistan. In contrast to India, which somehow managed to expropriate the rich cultural heritage of the Mauryas and the Guptas (see Basham 1967), Pakistan found itself almost without legitimating cultural history, since the key centres of Islamic civilization lay outside its borders. In addition, Pakistan has from its inception been afflicted by a pervasive and very real sense of insecurity, to the point where one scholar has actually referred to it as an 'insecurity state' (Thornton 1999, 171). The loss of East Pakistan in 1971 of course fuelled this sense, and it remains potent to this day. 
This has contributed to a number of striking pathologies which afflict Pakistan's body politic. First, Pakistan lacks a well-institutionalized and legitimated framework for politics. Instead, it has regularly witnessed periods of military rule-from 1958-62, 1969-72, 1977-88, and since October 1999-which have also blocked the flourishing of an impressive civilian elite in the intervening periods. While it has a powerful military, it lacks an effective state: government structures are riddled with corruption, and feudal power holders have a disproportionate influence on government decision-making. Second, resources are absorbed by the military which could better be spent on civil functions such as education. As a result, the state school system performs poorly, which increases the attractiveness of religious schools run by Islamic parties with a range of different agendas. In the 2001 UNDP Human Development Report, Pakistan ranked 127 th out of the 162 countries examined (United Nations Development Programme 2001, 13, 143). Third, Pakistan has witnessed an explosion of religious mobilization and sectarian conflict on its soil (Zaman 1998; Zaman 2002; Nasr 2000a; Nasr 2000b), as a result of the reverberations from the Iranian Revolution and of the flow of weapons into its territory from the war in Afghanistan (Goodson 2000). Fourth, the military continues to reflect the effects of the 'Islamization' programme of General Zia ul-Haq (1977-88), who 'encouraged Islamic conservatism and orthodoxy in the Army' (Rizvi 2000, 245). The most famous manifestation of this was General Hamid Gul, Head of Pakistan's Inter-Services Intelligence Directorate from 1987 to 1989, who became an ardent supporter of extremists such as the Taliban, and was damningly described by one observer as 'a man who had tried to play God with the fates of innocent people in another country because his own country had failed to live up to its promise' (Lamb 2002, 295). These pathologies underpinned concerns before September 2001 that Pakistan might at some point begin to slide into a state of incipient Talibanization (Maley 2001). With the crushing of the Taliban movement the immediate threat has receded, but there is little to suggest that Pakistan's current leadership has any workable strategies to address the country's longer-term problems. Unsettling times lie ahead.

\section{India as regional lynch-pin}

India, of course, dwarfs its Southwest Asian neighbours in a number of ways. It is one of only two countries with a population exceeding one billion, and is a military and industrial power of some significance. Indeed, the rise of India to the status of very substantial middle power-and some would say threshold great power-is perhaps the most significant long-term development in the region. These features of India's development, together with its status as a functioning democracy, deserve some further comment.

Size is sometimes seen as a barrier to the flourishing of democratic institutions, and the argument that only autocratic or one-party rule can maintain order in a state with a vast population surfaces from time to time. India provides a 
striking counter-example. With appropriate institutions, it is possible to protect the vital power of ordinary people to change their government without bloodshed. In India, these institutions have included federal structures which fragment power on a territorial basis, an independent judiciary which secures a separation of powers on a functional basis, and robust private markets and free media which secure a social separation of powers. Vigorous associational engagement provides additional protection against intercommunal violence (Varshney 2002). When Prime Minister Indira Gandhi sought to interfere with some of these institutions through the imposition of emergency rule in 1975, she paid a high price at the polls two years later. While there are some parts of India which are seriously afflicted with social tensions--including Kashmir, Gujarat, parts of Uttar Pradesh and Bihar, and the states in the extreme east of the country (Bajpai 2002)-fears that India could face a crisis of governability (Kohli 1990) have thus far failed to materialize. Nor has Hindu extremism colonized the commanding heights of the political system (Stern 2003, 188), despite the predominance of the Hindutva Bharatiya Janata Party for most of the 1990s. However, this could change if Deputy Prime Minister L.K. Advani, the party's ideologue, were to succeed Prime Minister Vajpayee as the country's leader; and as a country whose population is divided in complex ways, the risk of a sudden escalation of tension as a result of unforeseen events either at home or in the region can never be ruled out.

India's exercise of power has both 'hard' and 'soft' bases. Its hard power derives from its increasingly skilled population, industrial base and military capability. There is no doubt that the size of India's middle class has increased substantially in recent years, with some writers putting it as large as 300 million (Nayar and Paul 2003, 44)--that is, larger than the entire population of the United States. In purchasing-power parity terms, India is the fourth largest economy in the world (Cohen 2001, 27), lagging behind only the United States, China, and Japan. And militarily India is also a substantial power (Gordon 1995, 55-116), not only as a result of its nuclear capabilities, but also because of its active armed forces of 1.298 million personnel. The Indian Army has 58 tank regiments, 355 infantry battalions, and 190 artillery regiments; the navy 16 submarines and 27 principal surface combatants, including an aircraft carrier; and the air force 701 combat aircraft (International Institute for Strategic Studies, 2002).

Where India remains weak is in soft or 'reputational' power. In the 1950s, Prime Minister Nehru, described by Winston Churchill in his old age as 'the Light of Asia' (Gopal 1993, 470), managed to assume a prominent and effective role in the Commonwealth while also positioning himself as a key leader of the NonAligned Movement which took shape after the 1955 Bandung Conference. None of his successors was able to execute this tricky task with the same dexterity. The tolerant Indian response to the Soviet invasion of Afghanistan (Saikal 1989) did great damage to India's non-aligned credentials--Afghanistan, after all, had been an active participant at Bandung-and the collapse of the Soviet Union and the emergence of the United States as the world's largest power left in disarray the 
conceptual bases of India's attempts to shape its position in the world. To paraphrase Dean Acheson's famous comment about post-imperial Britain, India has lost its non-aligned status but is yet to find a role.

Yet if India is reputationally weak in global terms, it is still by far the most substantial power in Southwest Asia. Its occasional exasperation at the wider world's approaches to the region stems in part from what it sees as a skewed rationale for engagement. Particularly frustrating for India has been what its leaders regard as indulgent Western treatment of Pakistan. Well after Islamabad's direct backing of the Taliban became a matter of notoriety, the United States hesitated to pressure Pakistan over this support, let alone give backing to the anti-Taliban forces in Afghanistan (Benjamin and Simon 2002, 338-9). The United States feared that Pakistan was in such a dire state that its regime could fragment under pressure, clearing the way for an extremist regime that would have access to nuclear weapons. Pakistan shrewdly played up this fear in order to insulate itself from pressure. Since September 2001, the Pakistani regime of General Musharraf, brought to office in a military coup, has been treated with startling respect by the United States. While US approaches to Pakistan have varied over time (Kux 2001), there remains in Washington a residual respect for Pakistan as an ally from the Cold War era. However, from New Delhi's point of view, Pakistan has in effect been rewarded by the United States because it has been irresponsible and illmanaged. Yet in the long-run, India is not likely to find itself abandoned. India's democratic political system, substantial market, and open society make it a natural partner for the West in a way that Pakistan as presently configured cannot hope to be.

\section{Nuclear weapons proliferation}

If it were not for nuclear weapons, the security environment of South Asia would not be nearly as much cause for concern as it is. India tested a nuclear device in May 1974, and this, in the words of one observer, 'accelerated a Pakistani commitment to develop what [Pakistani] Prime Minister Bhutto called a "Muslim bomb"' (Thomas 1986, 46). Similarly, India's May 1998 'Pokhran II' tests, five in all, led to a series of seven Pakistani nuclear tests less than three weeks later which reconstituted South Asia as perhaps the world's riskiest theatre of nuclear competition. While some analysts of nuclear strategy had argued that possession of nuclear weapons could be expected to impose effective discipline upon the possessor (Waltz 1981), the idiosyncrasies of domestic politics, in Pakistan at least, understandably prompted scepticism as to whether such conclusions would continue to hold.

Nuclear weapons, and more importantly the existence of systems for their longrange delivery which are not vulnerable to a disabling first strike, give rise to a system in which the operating principle is deterrence rather than the balance of power. Different rationales for India's development of nuclear weapons have been developed. Some point to a need to deter China, others to deter Pakistan, while 
yet others relate nuclear capacity to prestige and global status (see Bajpai 2000; Tellis 2001, 252-366; Cohen 2001, 178-84). Whatever may be the case, one argument that is difficult to sustain is that testing in 1998 added either to India's security, or its political leverage. Pakistan's test (a predictable response given the psychology of the Pakistani leadership) wiped out the escalation dominance which India momentarily enjoyed as South Asia's sole nuclear power, and in addition heightened US concern about applying firm pressure to Pakistan, in a way which hardly advanced India's interests--although the United States was able to find a Pakistani pressure point, in the form of Prime Minister Nawaz Sharif, during the Kargil crisis.

In the absence of a broader settlement of the political tensions between India and Pakistan, neither is likely to be drawn into effective nuclear arms control regimes. The lesson of Washington's heavy-handed approach to Iraq and delicate approach to North Korea is that parties suspected to possess nuclear weapons substantially insulate themselves from pressure. Pakistan, which is markedly inferior in conventional forces to India, will not even agree to a 'no first use' arrangement, since the threat of escalation to the nuclear level is its main strategy for deterring an Indian attack. India, meanwhile, has blocked the ill-considered attempt to use the UN General Assembly to promote the Comprehensive Test Ban Treaty (Thakur and Maley 1999, 302). The best one might hope to achieve in the short run would be confidence building measures (CBMs) to avert the risk of unintended use: as Cohen puts it, 'The security of India in relation to Pakistan depends not on the quality of the Indian nuclear force or the rationality of an Indian decision-making system, but on the integrity of Pakistan's chain of command' (Cohen 2001, 186).

\section{Non-traditional security threats}

While nuclear weapons may pose the greatest threat of cataclysmic harm, the risks from lower-level, 'non-traditional' threats should not be underestimated. The US 'War Against Terror' at one level involves recognition of a potent new threat, but it is also a 'war' which has been prosecuted in an inconsistent and confusing fashion. In late 2001, US Secretary of State Colin L. Powell caused disquiet in New Delhi with remarks implying that 'moderate' Taliban might retain a role in Afghanistan (Constable 2001), and the United States subsequently infuriated India when, in a foolish move to shore up the position of President Musharraf, it permitted thousands of Taliban to be evacuated to Pakistan by air from the besieged Afghan city of Kunduz (Hersh 2002). India, not unreasonably, felt that it was highly likely that these individuals would be used to stir up trouble in Kashmir. Such misjudgements raise doubts about the quality of US strategic leadership in a war against terrorism, and as yet, there is little to suggest that the United States has accorded much thought to ways of addressing the deeper sociocultural schisms on which charismatic leaders draw in order to recruit shocktroops for terrorist actions. 
Narcotics production in particular has created a major source of revenue for criminal networks and terrorists, and has the potential to fuel large-scale internal armed conflict, as to a certain extent it did in Afghanistan (see Rubin 2000). Under the weight of a Taliban decree, opium production in Afghanistan in 2001 fell to just 185 tonnes; in 2002, it shot up to 3,400 (BBC News, 3 March 2003). One reason was that in its search for allies against al-Qa'ida, the United States struck bargains with warlords heavily inculpated in opium production, as graphically reported in the Australian Broadcasting Corporation $(\mathrm{ABC})$ television program Foreign Correspondent on 10 April 2002. One could hardly look for a better example of the greyness which in practice surrounds many key decisions made in the war against terrorism, and of the complexities in trying to work out how best to move forward.

\section{Conclusion}

Kanti Bajpai, one of the most penetrating observers of contemporary Southwest Asia, has observed that 'outside powers have an interest in South Asian stability as never before' (Bajpai 2003, 233). This is undoubtedly true, and it serves as a warning to capitals such as Washington, Beijing, and even Canberra not to be distracted by other dramatic events such as the US thrust against Iraq. Despite the Bush Administration's very Texan dislike for the complexities of 'nationbuilding', a power which aspires to shape the world to its image of how the world should be simply cannot' escape the responsibilities which 'nation-building' implies. The tasks involved are extremely complex (Maley 2002c), but if they are ignored, the backlash for a capital such as Washington could be very considerable. In 2002, US General Tommy R. Franks, Head of US Central Command, remarked that the "fact of the matter is that Afghanistan is a very dangerous place' (SBS Television News, 26 August 2002). He might have gone on to remark that until the time when its institutions are able to provide a bulwark against a re-emergence of extremism, there will be dangers not only for Afghans in Afghanistan, but also for Americans in the United States.

There are no magic solutions to Southwest Asia's complex problems of intrastate disruption, interstate rivalry, and insecurity in a region bristling with weapons, but two paths are worth following. First, major powers concerned to foster regional stability should seek to develop coherent, principled approaches to the region, and apply them consistently. The ad hoc involvement of key external powers has done little to foster an environment in which trust, such a scarce commodity in Southwest Asia, can be developed; too often, major powers have become involved in blatant pursuit of their own interests, and this provides little basis for local actors to put their faith in those powers as guarantors of security or order. Second, major powers, and international institutions, should begin a search for creative ways to address the interlocking security dilemmas which make Southwest Asia such a dangerous place. There is a need for a new security architecture that recognizes the importance of human security, that recognizes the 
risks posed by new security threats, and that fosters a recognition by all states that their neighbours have legitimate security concerns (Rubin et al. 2001). The states of the region have largely lost the ability to view these problems in proper perspective. The wider world has a role to play in helping them to move forward.

\section{References}

Atmar, Mohammed Haneef, and Jonathan Goodhand. 2002. 'Afghanistan: the challenge of "winning the peace"'. In Monique Mekenkamp, Paul van Tongeren, and Hans van de Veen (eds), Searching for Peace in Central and South Asia: an overview of conflict prevention and peacebuilding activities. Boulder: Lynne Rienner, pp. $109-40$.

Bajpai, Kanti. 2000. 'India's Nuclear Posture after Pokhran II', International Studies. $37: 4$, pp. $267-301$.

Bajpai, Kanti. 2002. Roots of Terrorism. New Delhi: Penguin Books.

Bajpai, Kanti. 2003. 'Managing Conflict in South Asia'. In Paul F. Diehl and Joseph Lepgold (eds), Regional Conflict Management. Lanham: Rowman and Littlefield, pp. 209-38.

Basham, A.L. 1967. The Wonder that was India. New Delhi: Rupa and Co.

Benjamin, Daniel, and Steven Simon. 2002. The Age of Sacred Terror. New York: Random House.

Bennett Jones, Owen. 2002. Pakistan: eye of the storm. New Haven: Yale University Press.

Canfield, Robert. 1992. 'Restructuring in Greater Central Asia: changing political configurations', Asian Survey. 32:10, pp. 875-87.

Cohen, Stephen P. 2001. India: emerging power. Washington DC: The Brookings Institution.

Constable, Pamela. 2001. 'U.S. Hopes to Attract Moderates in Taliban', Washington Post. 17 October.

Davis, Anthony. 1993. 'The Afghan Army', Jane's Intelligence Review. 5:3, pp. 134-9.

Dorronsoro, Gilles. 2002. 'Pakistan and the Taliban: state policy, religious networks and political connections', In Christople Jaffrelot (ed.), Pakistan: nationalism without a nation? London: Zed Books, pp. 161-78.

Dupree, Louis. 1973. Afghanistan. Princeton: Princeton University Press.

Ganguly, Rajat. 1998. Kin State Intervention in Ethnic Conflicts: lessons from South Asia. New Delhi: SAGE Publications.

Ganguly, Sumit, 1997. The Crisis in Kashmir: portents of war, hopes of peace. Cambridge: Cambridge University Press.

Goodson, Larry P. 2000. 'Foreign Policy Gone Awry: the Kalashnikovization and Talibanization of Pakistan'. In Craig Baxter and Charles H. Kennedy (eds), Pakistan 2000. Karachi: Oxford University Press, pp. 151-81.

Gopal, Sarvepalli. 1993. 'Churchill and India'. In Robert Blake and Wm. Roger Louis (eds), Churchill. Oxford: Oxford University Press, pp. 457-71.

Gordon, Sandy. 1995. India's Rise to Power in the Twentieth Century and Beyond. London: Macmillan. 
Hersh, Seymour M. 2002. 'The Getaway: questions surround a secret Pakistani airlift', The New Yorker. 28 January.

International Institute for Strategic Studies. 2002. The Military Balance 2002 2003. Oxford: Oxford University Press.

Khosa, Raspal S. 1999. 'The Siachen Glacier Dispute: imbroglio on the roof of the world', Contemporary South Asia. 8:2, pp. 187-209.

Kohli, Atul. 1990. Democracy and Discontent: India's crisis of governability. Cambridge: Cambridge University Press.

Kux, Dennis. 2001. The United States and Pakistan 1947-2000: Disenchanted Allies. Washington DC: Woodrow Wilson Center Press.

Lamb, Christina. 2002. The Sewing Circles of Herat: A Personal Journey Through Afghanistan. London: HarperCollins.

Maley, William. 1998. 'The Perils of Pipelines', The World Today. 54:8-9, pp. 231-2.

Maley, William. 2001. 'Talibanisation and Pakistan'. In Denise Groves (ed.), Talibanisation: extremism and regional instability in South and Central Asia. Berlin: Conflict Prevention Network: Stiftung Wissenschaft und Politik, pp. $53-74$

Maley, William. 2002a. The Afghanistan Wars. London: Palgrave Macmillan.

Maley, William. 2002b. 'The Reconstruction of Afghanistan'. In Ken Booth and Tim Dunne (eds), Worlds in Collision: terror and the future of global order. London: Palgrave Macmillan, pp. 184-93.

Maley, William. 2002c. 'Twelve Theses on the Impact of Humanitarian Intervention', Security Dialogue. 33:3, pp. 265-78.

Nasr, S.V.R. 2000a. 'The Rise of Sunni Militancy in Pakistan: The Changing Role of Islamism and the Ulama in Society and Politics'. Modern Asian Studies. 34:1, pp. $139-80$.

Nasr, S.V.R. 2000b. 'International Politics, Domestic Imperatives, and Identity Mobilization: sectarianism in Pakistan, 1979-1998', Comparative Politics. 32:2, pp. 171-90.

Nayar, Baldev Raj, and T.V. Paul. 2003. India in the World Order: searching for majorpower status. Cambridge: Cambridge University Press.

Pandey, Gyanendra. 2001. Remembering Partition: violence, nationalism and history in India. Cambridge: Cambridge University Press.

Rashid, Ahmed. 2000. Taliban: militant Islam, oil and fundamentalism in Central Asia. New Haven: Yale University Press.

Rizvi, Hasan-Askari, 2000. Military, State and Society in Pakistan. London: Macmillan.

Rubin, Barnett R. 2000. 'The Political Economy of War and Peace in Afghanistan', World Development. 28:10, pp. 1789-803.

Rubin, Barnett R. 2002. The Fragmentation of Afghanistan: state formation and collapse in the international system. New Haven: Yale University Press.

Rubin, Barnett R., Ashraf Ghani, William Maley, Ahmed Rashid, and Olivier Roy. 2001. Afghanistan: Reconstruction and Peacebuilding in a Regional Framework. Bern: KOFF Peacebuilding Reports $1 / 2001$, Swiss Peace Foundation. 
Saikal, Amin. 1989. 'The Regional Politics of the Afghan Crisis'. In Amin Saikal and William Maley (eds), The Soviet Withdrawal from Afghanistan. Cambridge: Cambridge University Press, pp. 52-66.

Stern, Robert W. 2003. Changing India. Cambridge: Cambridge University Press.

Tellis, Ashley J. 2001. India's Emerging Nuclear Posture: between recessed deterrent and ready arsenal. Santa Monica: RAND,

Thakur, Ramesh, and William Maley. 1999. 'The Ottawa Convention on Landmines: A Landmark Humanitarian Treaty in Arms Control?', Global Governance. 5:3, pp. 273-302.

Thomas, Raju G.C. 1986. Indian Security Policy. Princeton: Princeton University Press.

Thornton, Thomas Perry. 1999. 'Pakistan: fifty years of insecurity'. In Selig S. Harrison, Paul H. Kreisberg, and Dennis Kux (eds), India and Pakistan: the first fifty years. Cambridge: Cambridge University Press, pp. 170-88.

United Nations Development Programme. 2001. Human Development Report 2001: making new technologies work for human development. New York: Oxford University Press.

Varshney, Ashutosh. 2002. Ethnic Conflict and Civic Life: Hindus and Muslims in India. New Delhi: Oxford University Press.

Waltz, Kenneth N. 1981. The Spread of Nuclear Weapons: more may be better. Adelphi Paper no.171. London: International Institute for Strategic Studies.

Wimmer, Andreas, and Conrad Schetter. 2002. State Building First: recommendations for reconstruction and peace-making in Afghanistan. Bonn: Discussion Papers on Development Policy no. 45, Center for Development Research, University of Bonn.

Zaman, Muhammad Qasim, 1998. 'Sectarianism in Pakistan: the radicalization of Shi' $\mathrm{i}$ and Sunni identities', Modern Asian Studies. 32:3, pp. 689-716.

Zaman, Muhammad Qasim. 2002. The Ulama in Contemporary Islam: custodians of change. Princeton: Princeton University Press. 